\title{
Multi-level determinants of inward FDI ownership
}

Citation for published version (APA):

Bhupatiraju, S. (2014). Multi-level determinants of inward FDI ownership. UNU-MERIT. UNU-MERIT

Working Papers No. 085

Document status and date:

Published: 01/01/2014

Document Version:

Publisher's PDF, also known as Version of record

\section{Please check the document version of this publication:}

- A submitted manuscript is the version of the article upon submission and before peer-review. There can be important differences between the submitted version and the official published version of record.

People interested in the research are advised to contact the author for the final version of the publication, or visit the DOI to the publisher's website.

- The final author version and the galley proof are versions of the publication after peer review.

- The final published version features the final layout of the paper including the volume, issue and page numbers.

Link to publication

\footnotetext{
General rights rights.

- You may freely distribute the URL identifying the publication in the public portal. please follow below link for the End User Agreement:

www.umlib.nl/taverne-license

Take down policy

If you believe that this document breaches copyright please contact us at:

repository@maastrichtuniversity.nl

providing details and we will investigate your claim.
}

Copyright and moral rights for the publications made accessible in the public portal are retained by the authors and/or other copyright owners and it is a condition of accessing publications that users recognise and abide by the legal requirements associated with these

- Users may download and print one copy of any publication from the public portal for the purpose of private study or research.

- You may not further distribute the material or use it for any profit-making activity or commercial gain

If the publication is distributed under the terms of Article $25 \mathrm{fa}$ of the Dutch Copyright Act, indicated by the "Taverne" license above, 


\title{
UNITED NATIONS \\ UNIVERSITY
}

\author{
UNU-MERIT
}

\section{UNU-MERIT Working Paper Series}

\section{\#2014-085}

\section{Multi-level determinants of inward FDI ownership Samyukta Bhupatiraju}

Maastricht Economic and social Research institute on Innovation and Technology (UNU-MERIT) email: info@merit.unu.edu | website: http://www.merit.unu.edu

Maastricht Graduate School of Governance (MGSoG)

email: info-governance@maastrichtuniversity.nl | website: http://mgsog.merit.unu.edu

Keizer Karelplein 19, 6211 TC Maastricht, The Netherlands

Tel: (31) (43) 388 4400, Fax: (31) (43) 3884499 


\section{UNU-MERIT Working Papers}

ISSN 1871-9872

Maastricht Economic and social Research Institute on Innovation and Technology, UNU-MERIT

\section{Maastricht Graduate School of Governance MGSoG}

UNU-MERIT Working Papers intend to disseminate preliminary results of research carried out at UNU-MERIT and MGSoG to stimulate discussion on the issues raised. 


\title{
Multi-level Determinants of Inward FDI Ownership ${ }^{1}$
}

\author{
by \\ Samyukta Bhupatiraju ${ }^{2}$
}

\footnotetext{
${ }^{1}$ I am thankful to Prof. Bart Verspagen and Dr. Thomas Ziesemer for their suggestions. The views expressed in this paper are the views of the author and do not necessarily reflect the views and policies of UNU-MERIT or Maastricht University. All remaining errors are those of the author.

${ }^{2}$ Bhupatiraju, S., Maastricht University—UNU-MERIT, Keizer Karelplein 19, 6211 TC Maastricht,

The Netherlands, (bhupatiraju@merit.unu.edu)
} 


\begin{abstract}
In this paper, we empirically analyse the determinants of FDI ownership into developing countries. We do this by using firm-level data obtained from the Enterprise Surveys data of the World Bank and country level data from various sources. Using a multi-level logit model, we analyse how institutional and structural variables at both firm and country levels impact inward FDI. In our view, there is a gap between analysis at the country level studies and firm level studies on inward FDI. In this paper, we fill the gap by doing a multi-level regression analysis, taking into account both firm variables and country characteristics to explain inward FDI ownership. We find that firm structural characteristics and obstacles they face most affect inward FDI. While some macroeconomic variables such as GDP per capita, inflation and openness have a significant influence, other variables that measure institutional quality of a country do not have any statistically significant influence on FDI inflow.
\end{abstract}

Keywords: Multilevel analysis; Foreign ownership; Institutions JEL Codes: F20, O11, O12, O43 


\section{Introduction}

The influence of firm idiosyncratic characteristics on their decision to enter foreign markets has been dealt with in much detail in both theoretical and empirical literature. There is a host of empirical studies that analyse firm level determinants of FDI decisions as well as their modes of entry. Most often, these studies analyse firm specific advantages such as technological intensity, innovation capacity, product and process differentiation from domestic firms, capital intensity, R\&D activities, advertising (marketing and distribution skills) etc. to explain the entry of Multinational Enterprises (MNE's) into host countries (Blonigen 2005, Lee and Rugman 2012). The above mentioned variables describe the advantages that certain firms tend to have over others.

When analysing why some countries are better able to attract more FDI than others, studies look at the prevailing macroeconomic situation in the country, as well as how conducive the institutional set up is, for entering and doing business in that country. Exchange rate fluctuations, inflation variation, the availability or the lack of skilled labour and unskilled labour at lower wages, tax rates on corporate profits, etc. are among some of the aspects that are considered under the macroeconomic stability of host countries that influence MNE entry decisions. A second set of factors that are considered are the bureaucratic, judicial and the political situation of a country. A country with a weak legal protection of property rights is unlikely to attract MNE, considering the high risk of appropriation that would prevail. An excessive amount of bureaucratic hurdles will also discourage new entrants, since it would increase the cost of setting up a business. These costs are further hiked if the bureaucracy is coupled with higher levels of corruption. Thus the institutional quality of a country and its credibility are often are taken as important considerations for an MNE to enter a new market (Naude and Krugell 2007, Sharma and Bandara 2010, Seyoum 2009, 2011). Rule of law, democracy, low levels of corruption and flexible labour institutions are all said to be important country characteristics that most attract FDI inflows (Stein and Daude 2002, Daude and Stein 2007, Delbecque et al.2008, Pajunen 2008). The historical and current institutional set up of a country also influences its view on adopting foreign investment friendly policies. For example, while post-colonial Brazil welcomed and encouraged FDI to play an important role in its industrialisation and development, a newly independent India restricted entry of foreign capital and preferred to look inwards, rather than looking towards FDI related growth and development policies, due to the differences in the colonial institutions of the two countries. (Baer and Sirohi 2013). The impact of the quality of institutions on MNE decisions seems arguably simple and quite straight forward, but there is no clear consensus on how much and how relevant institutional quality actually impedes FDI inflows. Studies such as Wei (2000), Daude and Stein (2007), Dollar et al. (2005, 2006) and Kinda (2010) conclude that a weak institutional set up discourages FDI inflows into countries. On the other hand, studies such as Wheeler and Mody (1992), Singh and Jun (1995) do not find any significant evidence to conclude the same.

Dunning $(1988,2001)$ along with other studies (Rugman 1980, 1981) has emphasised that MNE's have firm-specific advantages that go hand-in-hand with host country conditions in encouraging FDI. FDI decisions are neither made solely based on firm characteristics, nor are they based entirely on host country conduciveness for business. Both these levels, independently and interactively form a certain environment that firms decide to take advantage of. In order to get a better understanding on what drives FDI inflows into countries, we need to analyse these hierarchical interactions in a more through fashion. Econometric studies that analyse what drives FDI inflows have either studied firm-level characteristics or have studied host country characteristics. To account for country level characteristics, these studies often used country dummies. In their paper "What matters to African firms?" Gleb et al. (2007) use the Enterprise Surveys to do a firm level analysis on firm perceptions of constraints as a function of firm characteristics, using sector and country fixed effects. They find that the constraints reported by firms strongly reflect country characteristics and their levels of income. Kinda (2010) analyses the impact of infrastructure problems using firm level data and country fixed effects to find that they strongly discourage FDI inflows. Smarzynska and Wei (2000) use firm-level data and test if corruption in host countries has an impact on inward US FDI. They find that it does indeed discourage US firms from investing in countries with a higher level of corruption. Kaufmann and Wei (1999) using data from firm-level surveys, find that firms that bribe more, face more bureaucracy rather than less.

Some country level studies that analyse the determinants of FDI include: Al-Sadig (2009) who uses country level panel data to estimate the effects of corruption on the location of FDI using fixed effects to control for country specific effects on corruption. He finds that controlling for institutional quality, the level of corruption in the country does not have a strong impact in reducing FDI inflows. Anghel (2005) analyses the effects of institutions on FDI 
inflows using cross-section data. They find that poor institutional quality significantly affects FDI inflows. Wernick et al. (2009) also find that FDI inflows into emerging and developing nations are dependent on strong institutions and business friendly macroeconomic policies and in turn influence economic growth. Seyoum (2009) also analyses the impact of the quality of formal institutions in a country on inward FDI. He finds that they strongly influence inward FDI. Seyoum (2011) finds that the existing informal institutions in countries also have an indirect effect on attracting/ discouraging inward FDI. Aristotelous and Fountas (1996) use pooled country level data to analyse macroeconomic determinants of FDI inflows into EU. They find that market size, and real exchange rate and tariff have a significant effect on inward FDI. Walsh and Yu (2010) use a GMM dynamic estimation on aggregate FDI inflows into developing countries as dependent on various macroeconomic, developmental and institutional variables. They find that inward FDI into the primary sectors are not as much affected by the various determinants, as are the secondary and tertiary sectors.

Very often, there is a tendency to extrapolate results found at the micro-level to a macro-level (Meentemeyer 1989). Results of macro-level or micro-level studies that study the various determinants of FDI tend to generalise their results across the hierarchical levels. For example Busse and Hefeker (2007) perform a cross-country analysis and find that the stability of governments and their democratic accountability, the presence of religious tensions, corruption and excessive bureaucracy, among others impact (total) inward FDI volumes. They conclude that "political risk and institutional indicators matter the most when multinational corporations confront decisions about where to invest in developing countries". While aggregated FDI flows are at a macro level, firm decisions are much more micro-level phenomena, that are influenced by other micro-level as well as macro-level variables.

In order to see if indeed such generalisations could be made, we perform a multi-level analysis that takes into account determinants of FDI at both the macro-level and the micro-level, and the inter and intra level interactions. Farla (2014) uses a multilevel model estimate the impact of foreign equity ownership and institutional quality on a firm's investment decisions. The author finds that firms with $100 \%$ foreign equity do not invest in fixed capital, and also that macroeconomic and institutional variables do not influence firm level decisions. The aim of this paper is to empirically analyse these multilevel interactions between firm-level advantages and host country characteristics that determine the amount of inward FDI in countries using multilevel model. In order to do this, we use the firm-level data from the Enterprise Surveys, which survey numerous developing countries, along with some macro-level variables collected from various sources, explained later in the paper. We specify a multilevel logit model to identify those firm-characteristics and host-country characteristics that raise the probability of inward FDI. The main results show that while firm-level perceptions of infrastructure and financial constraints affect FDI decisions, institutional quality measured at the country level does not have any significant impact on the same.

The rest of the paper is organised as follows. Section 2 describes the data used. Section 3 outlines the empirical methodology. Section 4 presents the results and the last section concludes the paper.

\section{Data}

\subsection{Micro data}

The analysis is based on the Enterprise Surveys data, collected and standardised in various developing countries over the years 2006-2011 by the World Bank. This comprehensive data set provides us a rich source of information on firm characteristics such as their size, ownership structure, firm perceptions of obstacles they face, such as corruption, telecommunications, electricity etc., as well as their sales and other production and finance variables. Compiled using country surveys during the period of 2006-2011, these data are a stratified random sample based on firm size, region and sector they belong to.

The dataset analyses 103 developing countries, with 20 countries surveyed twice during the time period 2006-2011. After omitting observations that have missing or incomplete data, we have 43,403 firms, of which about 5,010 firms have some level of FDI. Our dependent variable for this analysis is foreign ownership (FDI) ${ }^{3}$. We use a dummy

\footnotetext{
${ }^{3}$ To qualify as FDI, a firm should have at least $10 \%$ of their capital owned by foreign persons or organisations, as per the standard IMF definition.
} 
variable with a value of 1 if a firm has FDI and 0 otherwise. Approximately 12-13 percent of the firms surveyed had $10-100 \%$ of foreign ownership.

The independent variables of interest include firm structural characteristics and other characteristics. SIZE refers to the size of a firm measured by the number of employees a firm hires. It is a categorical variable ranging from small firms with 0-20 employees, medium firms with 20-99 employees to large firms with 100 or more employees. We take size dummies MEDIUM for (20-99 employees) and LARGE for 100 or more employees, with SMALL being the base. LNAGE accounts for the age of the firm in logs of the number of years a firm has been established at the time of the survey.

Figure 1: Share (\%) of firms by size

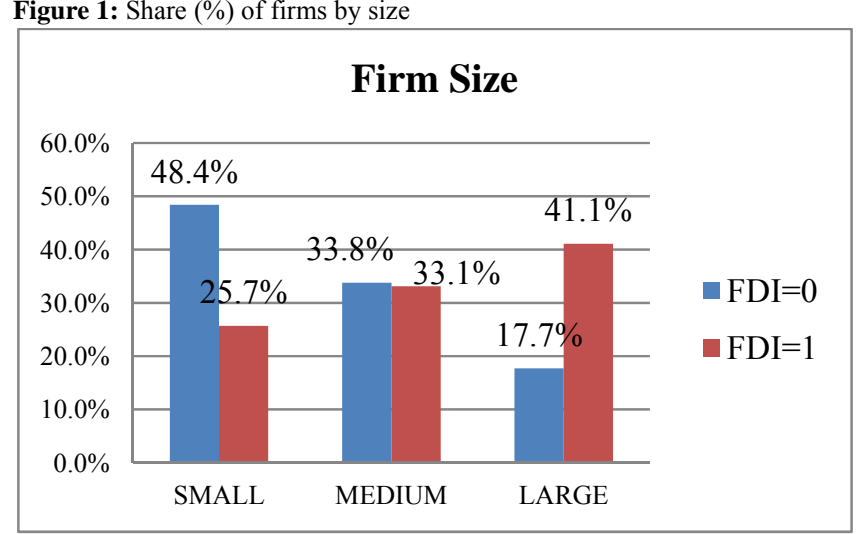

We construct index variables by performing Principle Component Analysis (PCA). The aim of doing a PCA is to reduce a number of correlated variables to a smaller number of latent variables that explain most of the variance in the data.

The survey captures the degrees of obstacles faced by firms, based on their perceptions. PHYSICAL 1 and PHYSICAL 2 are index variables capturing physical infrastructure obstacles faced by firms. These variables include constraints faced by firms with respect to (i) transportation of goods, supplies and inputs, (ii) electricity to current operations, and if they are accessible to clients and suppliers, using (iii) email and (iv) website. Transportation and electricity obstacles are categorical variables that take five values, namely, no major obstacle, minor obstacle, moderate obstacle, major obstacle or very severe obstacle. Email and web are dummy variables that account for firms either using or not using these facilities to communicate with clients and suppliers. They account for the lack of telecommunication infrastructure within a country ${ }^{4}$. In order to keep in line with the way the other obstacles have been defined, we define the email and web dummies such that if firms use email and web they are 0. PHYSICAL 1 captures the lack of internet facilities as a channel of communication between firms and their clients and suppliers, while PHYSICAL 2 captures transportation and electricity obstacles. Together these two components explain 72\% of the variance in the data. We expect PHYSICAL 1 and PHYSICAL 2 to have a negative sign.

INFRA 1 and INFRA2 are index variables that capture the firm's perception on obstacles to both physical and financial obstacles all taken together. In other words, we perform a PCA using email, web, transportation, electricity and financial access (FINANCIAL). FINANCIAL is a categorical variable that measures how much of an obstacle access to finance is taking five values, namely, no major obstacle, minor obstacle, moderate obstacle, major obstacle or very severe obstacle. We expect obstacles to financial access to have a negative impact on FDI. We do this to see how all obstacles taken together affect the results. We begin the analysis using INFRA 1 and INFRA 2. We then proceed to using PHYSICAL 1, PHYSICAL 2 and FINANCIAL separately to assess their impact on FDI. Table 1a shows the results of the PCA's all index variables. INFRA 1 has a first component which explains $32 \%$ of the variance. All the variables in INFRA 1 have high and similar weights, thus representing an overall lack of

\footnotetext{
${ }^{4}$ Of those firms which use emails to communicate with their clients and suppliers only $60 \%$ of them also use a website as well, and of those firms which do not use emails about $3.3 \%$ use a website.
} 
infrastructural facilities that pose a hindrance to businesses. INFRA 2 explains $29.59 \%$ of the remaining variance. We expect INFRA 1 and INFRA 2 to have a negative sign as well.

INS is another index variable that captures the institutional obstacles firms face. This variable includes (i) corruption as an obstacle to current operations, (ii) crime, theft and disorder as an obstacle and (iii) property rights i.e., if the firm considers the court system as fair, impartial and uncorrupted. Here again, obstacles to corruption and crime are categorical variables taking five values ranging from no obstacle to severe obstacle. Property rights on the other hand is a categorical variable taking four values, namely, strongly disagree, tend to disagree, tend to agree and strongly agree. For INS we find that the first component explains about $51 \%$ of the variance. We use only the first component and this captures the quality of the institutional set up in which firms operate. We expect a negative coefficient on this variable.

Table 1a: Principal Components of all index variables

\begin{tabular}{lllll}
\hline VARIABLES & INFRA 1 & INFRA 2 & PHYSICAL 1 & PHYSICAL 2 \\
\hline Email & 0.5064 & -0.4756 & 0.7024 & -0.0002 \\
Web & 0.5162 & -0.4634 & 0.7008 & 0.0109 \\
Electricity & 0.433 & 0.4212 & 0.0825 & 0.7078 \\
Transportation & 0.3239 & 0.5527 & -0.0932 & 0.7063 \\
Financial & 0.4299 & 0.276 & & 0.6496 \\
Corruption & & & & 0.5698 \\
Crime & & & 1.35277 & -0.5034 \\
Proprights & 1.60265 & 1.47968 & 1.52976 & 0.3382 \\
Eigen Value & 0.3205 & 0.2959 & 0.3824 & 0.5166 \\
Explained \% & & & \\
\hline
\end{tabular}

SKILL refers to the degree of obstacle firms face due to lack of skilled labour i.e., inadequately educated workforce ${ }^{5}$. This is a categorical variable with the same scale of five values ranging from no obstacle to very severe obstacle. This seems particularly important when we study FDI into developing countries. Although it is likely that foreign firms enter less developed countries for their cheap labour, inadequate education would pose a problem for firms. We therefore expect a negative relationship between SKILL and FDI. AGLOM measures the attractiveness of a sector-region for foreign firms to invest. This is constructed by taking the number of foreign firms present in a given sector in a given region. The Enterprise Surveys classify the region from within a country that the firm belongs to. For example, in Chile firms from the regions of Antofagasta, Bío Bío, Los Lagos, Santiago and Valparaíso are included in the survey. Similarly in Afghanistan firms from six regions, namely Hirat, Jalalabad, Kabul, Kandahar, Mazar and 5 Smaller Cities (Bamyan, Ghazni, Khost, Kunduz, Pul-E-Khumri) taken together are surveyed. AGLOM thus measures the attractiveness of these sector-regions to foreign firms. Table (A) in the Appendix gives the variable descriptions.

There are 15 broad sectors under which each firm has been classified in the data. In this chapter we re-classify these into 8 sectors as follows: 1) Textiles, Leather and Garments; 2) Food; 3) Metals and machinery, Auto and Auto parts; 4) Chemicals and Pharmaceuticals; 5) Electronics, Wood and furniture, Non-metallic and plastic materials and Other manufacturing; 6) retail and wholesale trade; 7) Hotels and restaurants and Other services and 8) Construction, transportation etc. The reclassification is done to avoid having too few observations in region-sector averages which will be discussed below.

\subsection{Macro data}

Some countries are able to attract more FDI than others. These cross country differences in FDI inflows come from differences in their macroeconomic and institutional conditions. When considering macroeconomic differences between countries, an obvious first choice is GDP per capita (we use the log of current USD prices taken from the

\footnotetext{
${ }^{5}$ For some firms, the questions on the degree of obstacles do not apply. For these firms, it has been assumed that that particular obstacle is not an obstacle.
} 
World Bank database (2012)) which we refer to as LGDPPC 6 . As we study FDI inflows into developing countries, we are interested in the impact the general level of development has on the dependent variable. We thus take GDP per capita as an indicator of the level of development of a country. The level of GDP per capita reflects investment opportunities. Asiedu (2002) explains that GDP per capita and the risk of investment are inversely related, implying that the returns have to be increased in order to compensate this higher rate of risk. Since we use mainly developing countries we expect the sign to be negative.

TAXRATE refers to the total tax rate as a percentage of commercial profits. This variable is taken from the World Bank database (2012). This tax rate measures the "amount of taxes and mandatory contributions payable by businesses after accounting for allowable deductions and exemptions as a share of commercial profits". Personal income tax, sales taxes, value added taxes and goods and services taxes are excluded. Host countries try to attract FDI by providing various incentives for firms to encourage investments in their economies. One such way of promoting FDI has been to reduce corporate tax rates. Studies such as Hartman $(1984,1985)$ find that transfer FDI ${ }^{7}$ is not sensitive to tax rates, while Sato (2012), Bénassy-Quéré et al. (2005) etc., find a significant negative impact of the same on FDI. Devereux and Freeman (1995) on the other hand find that the country context tax influences FDI. Studies like those mentioned above, tend to take country or industry level tax rates to understand firm level decisions (Blonigen 2005).

Host country attractiveness is further enhanced by macroeconomic stability in markets. High inflation tends to increase uncertainty and is assumed to discourage FDI in general. Furthermore this uncertainty limits a firm's price setting plans in the long run (Sato 2012, Buckley et al.2007). INFLATION is measured by the growth rate of the GDP deflator, showing the rate of price changes in a year, taken from the World Bank database (2012). We expect a negative relationship between the two.

OPENK accounts for openness to trade measured by net exports as a percentage of GDP, taken from the Penn World Table 7.1 (Heston et al.2012). Trade openness measures the level of trade protection of a country. One expects openness to be positively correlated to FDI (Cuadros, Orts \& Alguacil 2004, and Alguacil et al.2010). We use the financial openness indicator (KAOPEN) developed by Chinn and Ito (2008). KAOPEN measures the "extent and intensity" of capital controls of countries. Adams (2009) and Alfaro et al.(2010) among others argue that when host country financial markets are open, they allow for more efficient movement of foreign capital. Both these measures of openness are expected to have a positive effect on FDI. Additionally we control for LABOURPARTICIPATION, which is the labour participation measured by the proportion of working age population which is economically active (aged 15 years or older). Higher labour participation rates imply more willing workers, and thus a higher labour supply. A higher labour supply leads to wage competition effects that foreign firms then would want to take advantage of. We thus expect a positive relationship between labour participation and FDI inflows.

Institutional quality, especially in developing countries is likely to be an important determinant of FDI inflows. Good institutions tend to reduce transaction costs, by eliminating corruption, providing guaranteed property rights, ensuring justice etc. To capture the institutional conditions in a country, we use legal rights and business days. LEGALRIGHTS measures the degree of protection given to lenders and borrowers, given the country's bankruptcy laws. BIZDAYS measures the number of calendar days required to start a business (even if it requires additional costs, the fastest number of days are taken). We expect that a better institutional environment in a country increases its attractiveness as a destination for FDI.

We also use the World Governance Indicators (WGI) to account for institutional quality at the country level as an indicator of the country institutional quality. The WGI include Voice and Accountability, Political Stability and Absence of Violence, Government, Regulatory Quality, Rule of Law, Control of Corruption ${ }^{8}$. Since these variables are highly correlated to each other, we do a PCA on the 6 world governance indicators. The first latent component of this PCA explains $79 \%$ of the variance. Table $1 \mathrm{~b}$ shows the weights of each of the six variables in the first Eigen vector. This variable we call WGI. We can see that all the variables have similar weights, contributing almost equally to the scores.

\footnotetext{
${ }^{6}$ GDP per capita are taken according to the country-year of the Enterprise Surveys.

${ }^{7}$ Blonigen (2005) refers to FDI through new capital transferred to host countries as transfer FDI as opposed to FDI financed by retained earnings.

${ }^{8}$ The definitions for each of the variables are in Table (B) the appendix.
} 
Table 1b: Variables of the WGI indicator

\begin{tabular}{ll}
\hline Variable & WGI \\
\hline Voice & 0.409 \\
Stability & 0.341 \\
effectiveness & 0.423 \\
Regquality & 0.403 \\
Ruleoflaw & 0.437 \\
corruption & 0.43 \\
Eigen Value & 4.733 \\
Expl. Proportion & 0.79 \\
\hline
\end{tabular}

\section{Empirical Methodology}

Our aim in this paper is to determine which characteristics influence if a firm invests in foreign markets or not. We also want to find out if these characteristics are conditional on the host country characteristics, i.e., why is one country able to attract more FDI than another country. A multi-level analysis is required when we know that a hierarchical structure exists in the data. As is apparent, firms are nested within countries and therefore firm-level decisions are usually not independent of country characteristics, be it policy/law related or just dependent on the current macro-economic situation in the country, which is the assumption of single level models (Goldstein 2003, Goedhuys and Srholec 2010, Srholec 2010). We therefore use a multi-level model ${ }^{9}$ with firms at level-1 and country characteristics at level-2. This allows us to explain a part of the total variance by country context, with more accurate standard errors.

Since our dependent variable is a dummy variable, we have to account for this by using a multi-level logit model:

$$
\begin{aligned}
& E\left(F D I_{i j}=1 \mid \beta_{j}\right)=\varphi_{i j} \\
& \log \left[\frac{\varphi_{i j}}{\left(1-\varphi_{i j}\right)}\right]=\beta_{0 j}+\beta_{1} X_{i j}+\beta_{2} Z_{j}+u_{j}+e_{i j}
\end{aligned}
$$

for firm $i$ and country $j$, where $\beta_{0}+\beta_{1} X_{i j}+\beta_{2} Z_{j}$ is the deterministic part of the model and $u_{j}+e_{i j}$ is the random part. Further, $u_{j} \sim \mathrm{N}\left(0, \sigma_{u}^{2}\right)$; and $e_{i j} \sim \mathrm{N}\left(0, \sigma_{e}^{2}\right)$. From equation (2) we obtain different average outcomes for each group (country).

FDI is the binary dependent variable (that is always at the lowest level, i.e., firms). The level-1 predictors which are firm level variables given by $X_{\mathrm{ij}}$ include LNAGE, SIZE (MEDIUM, LARGE), AGLOM, INFRA, PHYSICAL, FINANCIAL, INS and SKILL. Level-2 predictors which are country level variables given by $Z_{\mathrm{j}}$, include LGDPPC, TAXRATE, LABOURPARTICIPATION, INFLATION, OPENK, KAOPEN, LEGALRIGHTS, BIZDAYS and WGI.

The reasons for using a multi-level model as opposed to a regular fixed-effects model are also evident. If we use a non-hierarchical model, the statistical significance of level-1 variables is overestimated. Further, the standard errors of level-2 or group level variables will also be affected (Goldstein 2003). Unlike in the fixed-effects model where the groups are taken into account by taking dummies for each group, a multi-level model allows us to distinguish between observed and unobserved group characteristics (Rabe-Hesketh and Skrondal 2008).

Perceptions of firms tend to be endogenous, i.e. identical conditions can be perceived differently by different firms based on their size, ownership etc., (Kinda 2010). Gleb et al.(2007) find that larger firms tended to complain more about physical infrastructure constraints, whereas smaller firms cited financial obstacles more frequently. In order to overcome this endogeneity (since the data is collected based on the perceptions of firms), infrastructural obstacles are thus are instrumented by sector-region averages of these variables. Based on Dollar et al.(2005), Aterido et al. (2007) and Kinda (2010), these sector-region averages tend to be exogenous by default, since only $12 \%$ of our firms are FDI firms.

\footnotetext{
${ }^{9}$ These models are also known as random-coefficient or mixed effects models.
} 


\section{Results}

We begin by analysing the firm level determinants of FDI flows. Estimation (1) of Table 2 shows the 'null' or the 'empty' model. This model estimates: $F D I_{i j}=\beta_{0 j}+u_{j}+e_{i j}$ where $\beta_{0 j}$ represents the average over country fixed effects, and $u_{j}$ and $e_{i j}$ are the random effects at the country and firm level respectively. The purpose of this model is to investigate, without specifying any particular variables yet, how much of the FDI inflows can be attributed to the idiosyncratic characteristics of the firms themselves, and how much can be attributed to the country into which these investments flow. The 'random' part of the model, gives us these details. We can calculate the share of each level as a percentage of total variance. The variance partition coefficients (VPC's) measure the proportion of variation that lies at each level. When there are only two levels, the VPC's are the same as the inter class correlation coefficients (ICC's) which explain the correlation of observations within groups (countries), given by $\rho$. For a two level model the VPC and ICC at the firm level are given by $I C C_{e}=V P C_{e}=\frac{\sigma_{e}^{2}}{\left(\sigma_{e}^{2}+\sigma_{u}^{2}\right)}$ and the country level VPC and ICC are given by $I C C_{u}=V P C_{u}=\frac{\sigma_{u}^{2}}{\left(\sigma_{e}^{2}+\sigma_{u}^{2}\right)}$ where $\sigma_{e}^{2}$ is the firm level variance of $e_{i j}$ and $\sigma_{u}^{2}$ is the variance of $u_{j}$. These ICC's allow us to see how much of the variance of FDI decisions can be attributed to country level variables as well as to the sectors.

Estimation (1) gives us an intra-class correlation of $(\rho=0.12)$ to represent the variance attributed to differences between countries in receiving FDI inflows, i.e., the country context explains about $12 \%$ of FDI inflows. Although this is a relatively small part of the variance, it is not negligible and is significant at the $1 \%$ level. This implies that there are significant contextual differences between countries. We proceed further by introducing firm level explanatory variables in the remaining estimations of Table 2.

Following Kinda (2010) we first estimate the impact of INFRA on FDI prospects (estimation (2) in Table 2, and then estimate the impact of PHYSICAL and FINANCIAL infrastructure constraints separately in estimation (3). In Table 2 we do not instrument any of the variables. Estimation (2) shows the results of a fixed effects logit regression. As we can see, all the covariates are highly significant. We find that the age of the firm (LNAGE) has a negative effect, indicating that older firms are less likely to be foreign owned (partly or wholly). SIZE of the firm has a positive impact, meaning that larger firms are more likely to be foreign owned. AGLOM is strongly significant, implying that presence of other firms in the same sector in the region has a positive effect on attracting further FDI. This result is different from what Kinda (2010) finds in all regressions. This could be due to the fact that we use different sector categorisations. Further, INFRA 1 (infrastructure constraints) has a highly significant negative impact, implying that the lack of email and web (internet) infrastructural constraints are not likely to discourage FDI inflows. This could be because firms which do not have email and web do not need it for their operations. While $86 \%$ of firms with FDI use email and $60 \%$ use websites. However, obstacles of electricity and transportation seem to have an unexpected positive sign. The coefficients on this variable are small (0.06). Among the firms that have FDI, about $24 \%$ of them think transportation is a major to severe obstacle and $37 \%$ think electricity is a severe obstacle. The positive coefficient on this variable may be interpreted as follows: the lack of infrastructure is dependent upon the level of overall development in a country. The rate of return on investment in countries with a lower level of development could be higher than in those countries. Estimation (3) shows the estimations of a fixed effects logit regression when the obstacles are divided into PHYSICAL (PHYSICAL 1 and PHYSICAL 2) and FINANCIAL infrastructure constraints also show similar effects. Obstacles to both PHYSICAL 1 and FINANCIAL infrastructure have a significantly negative effect on FDI ownership. The coefficient on PHYSICAL 1 shows that the availability of internet resources increases FDI, while the lack of financial access decreases FDI. PHYSICAL 2 again has a small but positive coefficient and is highly significant.

To check the robustness of the fixed effects results, we have random effects estimations in (4) and (5), which have results similar to (2) and (3) respectively. The interclass correlations for both the estimations is approximately $20 \%$ $(\rho=0.20)$. This is higher than before (in estimation 1 ) because now a part of the firm-level variance in equation (1) is captured by firm-level variables, and hence the firm-level variance due to unobserved firm-level variables is reduced. However, still the firm-level variance is much higher than country level variance, in turn showing that firm characteristics are more relevant than country characteristics in explaining inward FDI decisions of firms. However, 
we cannot disregard country effects in explaining FDI, showing that multi-level interactions should indeed be taken into account, while analysing the determinants of FDI.

Table 2: Estimations of firm level variables without INS and SKILL

\begin{tabular}{|c|c|c|c|c|c|}
\hline & (1) & (2) & (3) & (4) & (5) \\
\hline \multirow{3}{*}{ VARIABLES } & FDI & FDI & FDI & FDI & FDI \\
\hline & & fixed & fixed & random & random \\
\hline & & effects & effects & effects & effects \\
\hline \multirow[t]{2}{*}{ LNAGE } & & $-0.28 * * *$ & $-0.28 * * *$ & $-0.28 * * *$ & $-0.29 * * *$ \\
\hline & & $(0.02)$ & $(0.02)$ & $(0.02)$ & $(0.02)$ \\
\hline \multirow[t]{2}{*}{ MEDIUM } & & $0.7 * * *$ & $0.7 * * *$ & $0.7 * * *$ & $0.7 * * *$ \\
\hline & & $(0.04)$ & $(0.04)$ & $(0.04)$ & $(0.04)$ \\
\hline \multirow[t]{2}{*}{ LARGE } & & $1.71^{* * *}$ & $1.69^{* * *}$ & $1.7^{* * *}$ & $1.69^{* * *}$ \\
\hline & & $(0.048)$ & $(0.048)$ & $(0.048)$ & $(0.048)$ \\
\hline \multirow[t]{2}{*}{ AGLOM } & & $0.03^{* * *}$ & $0.03 * * *$ & $0.03 * * *$ & $0.03 * * *$ \\
\hline & & $(0.002)$ & $(0.002)$ & $(0.001)$ & $(0.001)$ \\
\hline \multirow[t]{2}{*}{ INFRA 1} & & $-0.36^{* * *}$ & & $-0.35 * * *$ & \\
\hline & & $(0.017)$ & & $(0.017)$ & \\
\hline \multirow[t]{2}{*}{ INFRA 2} & & $0.254 * * *$ & & $0.251 * * *$ & \\
\hline & & $(0.016)$ & & $(0.016)$ & \\
\hline \multirow[t]{2}{*}{ PHYSICAL 1} & & & $-0.40 * * *$ & & $-0.39 * * *$ \\
\hline & & & $(0.018)$ & & $(0.018)$ \\
\hline \multirow[t]{2}{*}{ PHYSICAL 2} & & & $0.06^{* * *}$ & & $0.063^{* * *}$ \\
\hline & & & $(0.015)$ & & $(0.015)$ \\
\hline \multirow[t]{2}{*}{ FINANCIAL } & & & $-0.18 * * *$ & & $-0.18 * * *$ \\
\hline & & & $(0.013)$ & & $(0.013)$ \\
\hline \multirow[t]{2}{*}{ Constant } & $-1.91 * * *$ & & & $-2.34 * * *$ & $-2.03 * * *$ \\
\hline & $(0.07)$ & & & $(0.12)$ & $(0.122)$ \\
\hline$\rho$ & 0.12 & & & 0.20 & 0.19 \\
\hline LR Chi2 & 1644.21 & & & 1969.04 & 1956.48 \\
\hline LR df(1) & $* * *$ & & & $* * *$ & $* * *$ \\
\hline \# of firms & 43,403 & 43,403 & 43,403 & 43,403 & 43,403 \\
\hline \# of countries & 103 & 103 & 103 & 103 & 103 \\
\hline
\end{tabular}

Standard errors in parentheses

$* * * \mathrm{p}<0.01, * * \mathrm{p}<0.05, * \mathrm{p}<0.1$

All estimations include Sector dummies.

The Hausman test results in our case show that fixed effects models are preferred to random effects models (as is typically the case in cross-country yearly data). Since we want to fit a multi-level model with both firm and country level variables fitting a fixed effects model is not possible. The Enterprise Surveys measure obstacles faced by firms based on their perceptions. When using these subjective measures to account for the investment climate in a country, we are bound to encounter endogeneity issues. Endogeneity arises due to the reason that firms may assess the same investment climate differently, based on their own performance or efficiency. For example, more efficient firms are likely to find a way around obstacles of financial access while those that are not as efficient may face more problems in obtaining finance. Dollar et al. (2005) use sector-region averages as instrument. They reason that these sectorregion averages would allow us to capture the investment climate that is relevant to all firms in a particular sector, located in that particular region. Lall and Mengistae (2005) argue that location decisions of small and medium firms are more or less exogenous and thus this would be a valid instrument. Since our dataset consists mainly of small and medium size firms, we also use the same method of instrumenting. We ensure that there are at least four firms in 
each sector-region. This way of instrumenting has also been used by Kinda (2010) and Aterido et al. (2007) among others.

Using this method of instrumenting for INFRA 1, INFRA 2, PHYSICAL 1, PHYSICAL 2, and FINANCIAL, we estimate the random effects model. Estimations (6) onwards, in Table 3 give the results of the iv-logit estimations. While the results remain similar in terms of direction and significance the coefficients on INFRA1 and INFRA 2 in estimation (6) are larger. In the case of INFRA 2 it makes a particularly large difference. Similarly, in estimation (7), the coefficients on PHYSICAL 2 when instrumented for, are larger, than in the case of PHYSICAL 1 and FINANCIAL.

We add other firm level variables, namely, INS and SKILL to the firm level explanatory variables (instrumented by their sector-region averages). Estimation (8) and (9) shows these results. We again find that the coefficients on INFRA 2 and PHYSICAL 2 are higher when we take into account the two new variables. INS has an unexpected positive sign but is not significant in the estimations (8) and (9). On the other hand SKILL is highly significant at a $1 \%$ level, but has a negative coefficient showing that FDI inflows find lack of education an obstacle. The unexplained variance given by $\rho$ is between 0.2 and 0.19 as in earlier estimations. The LR tests are significant and thus show that a multi-level understanding of the dependent variable is necessary.

Table 3: Estimations of firm level variables without INS and SKILL

\begin{tabular}{|c|c|c|c|c|c|c|}
\hline & (6) & (7) & (8) & (9) & (10) & (11) \\
\hline & FDI & FDI & FDI & FDI & FDI & FDI \\
\hline VARIABLES & iv-logit & iv-logit & iv-logit & iv-logit & iv-logit & iv-logit \\
\hline \multirow[t]{2}{*}{ LNAGE } & $-0.25 * * *$ & $-0.25 * * *$ & $-0.25 * * *$ & $-0.25 * * *$ & $-0.25 * * *$ & $-0.25 * * *$ \\
\hline & $(0.02)$ & $(0.02)$ & $(0.02)$ & $(0.02)$ & $(0.02)$ & $(0.02)$ \\
\hline \multirow[t]{2}{*}{ MEDIUM } & $0.9^{* * *}$ & $0.9 * * *$ & $0.9 * * *$ & $0.9 * * *$ & $0.9 * * *$ & $0.9 * * *$ \\
\hline & $(0.04)$ & $(0.04)$ & $(0.04)$ & $(0.04)$ & $(0.04)$ & $(0.04)$ \\
\hline \multirow[t]{2}{*}{ LARGE } & $2.03 * * *$ & $2.03 * * *$ & $2.04 * * *$ & $2.04 * * *$ & $2.03^{* * *}$ & $2.04 * * *$ \\
\hline & $(0.05)$ & $(0.05)$ & $(0.05)$ & $(0.05)$ & $(0.05)$ & $(0.05)$ \\
\hline \multirow[t]{2}{*}{ AGLOM } & $0.025 * * *$ & $0.025 * * *$ & $0.025 * * *$ & $0.025 * * *$ & $0.025 * * *$ & $0.025 * * *$ \\
\hline & $(0.001)$ & $(0.001)$ & $(0.001)$ & $(0.001)$ & $(0.001)$ & $(0.001)$ \\
\hline \multirow[t]{2}{*}{ INFRA 1} & $-0.38 * * *$ & & $-0.39 * * *$ & & $-0.38 * * *$ & $-0.39 * * *$ \\
\hline & $(0.05)$ & & $(0.05)$ & & $(0.05)$ & $(0.05)$ \\
\hline \multirow[t]{2}{*}{ INFRA 2} & $0.37 * * *$ & & $0.45^{* * *}$ & & $0.38^{* * *}$ & $0.45^{* * *}$ \\
\hline & $(0.05)$ & & $(0.05)$ & & $(0.048)$ & $(0.05)$ \\
\hline \multirow[t]{2}{*}{ PHYSICAL 1} & & $-0.48^{* * *}$ & & $-0.54 * * *$ & & \\
\hline & & $(0.05)$ & & $(0.05)$ & & \\
\hline \multirow[t]{2}{*}{ PHYSICAL 2} & & $0.18^{* * *}$ & & $0.22 * * *$ & & \\
\hline & & $(0.06)$ & & $(0.06)$ & & \\
\hline \multirow[t]{2}{*}{ FINANCIAL } & & $-0.26^{* * *}$ & & $-0.2 * * *$ & & \\
\hline & & $(0.05)$ & & $(0.05)$ & & \\
\hline \multirow[t]{2}{*}{ INS } & & & 0.02 & 0.027 & -0.04 & \\
\hline & & & $(0.06)$ & $(0.06)$ & $(0.05)$ & \\
\hline \multirow[t]{2}{*}{ SKILL } & & & $-0.21 * * *$ & $-0.2 * * *$ & & $-0.21 * * *$ \\
\hline & & & $(0.05)$ & $(0.05)$ & & $(0.05)$ \\
\hline \multirow[t]{2}{*}{ Constant } & $-2.56 * * *$ & $-2.13 * * *$ & $-2.19 * * *$ & $-1.835^{* * *}$ & $-2.47 * * *$ & $-2.136 * * *$ \\
\hline & $(0.13)$ & $(0.16)$ & $(0.16)$ & $(0.188)$ & $(0.12)$ & $(0.146)$ \\
\hline$\rho$ & 0.21 & 0.21 & 0.21 & 0.20 & 0.21 & 0.20 \\
\hline LR Chi2 & 1656.07 & 1669.54 & 1552.97 & 1565.04 & 1650.35 & 1555.42 \\
\hline LR df(1) & $* * *$ & $* * *$ & $* * *$ & $* * *$ & $* * *$ & $* * *$ \\
\hline \# of firms & 43,403 & 43,403 & 43,403 & 43,403 & 43,403 & 43,403 \\
\hline
\end{tabular}




\begin{tabular}{llllll}
\hline \# of countries 103 & 103 & 103 & 103 & 103 & 103 \\
\hline Standard errors in parentheses & & & & \\
$* * * \mathrm{p}<0.01, * * \mathrm{p}<0.05, * \mathrm{p}<0.1$ & & & & \\
All estimations include Sector dummies. & & &
\end{tabular}

Table 4 shows the correlations between the explanatory variables. To see if these correlations affect the results we drop INS (in estimation 10) and SKILL (in estimation 11) ${ }^{10}$. We find that the results are robust to these changes. We further check the variance inflation factor and find that it is at an acceptable level ${ }^{11}$.

Table 4: Correlations between explanatory variables

a) for estimations (6) and (8)

\begin{tabular}{lllll}
\hline & INFRA 1 & INFRA 2 & INS & SKILL \\
\hline INFRA 1 & 1.00 & & & \\
INFRA 2 & -0.23 & 1.00 & 1.00 & \\
INS & 0.03 & 0.49 & 0.54 & 1.00 \\
SKILL & -0.26 & 0.64 & & \\
\hline
\end{tabular}

b) for estimations (7) and (9)

\begin{tabular}{|c|c|c|c|c|c|}
\hline & PHYSICAL 1 & PHYSICAL 2 & INS & SKILL & FINANCIAL \\
\hline PHYSICAL 1 & 1.00 & & & & \\
\hline PHYSICAL 2 & 0.15 & 1.00 & & & \\
\hline INS & -0.25 & 0.38 & 1.00 & & \\
\hline SKILL & -0.55 & 0.23 & 0.54 & 1.00 & \\
\hline FINANCIAL & 0.25 & 0.58 & 0.27 & 0.20 & 1.00 \\
\hline
\end{tabular}

So far we find that all the firm level variables that we include have a significant impact on the dependent variable. Further, we find that the (remaining) variance at the firm level is much larger than the variance at the country-level in explaining FDI inflows. However, we find that the estimated values of $\rho$ indicates a country level dependence of about 0.2 which is consistently significant (as given by the LR tests) and thus indicate the presence of country level effects that cannot be ignored when analysing FDI inflows.

In order to take into account these country level effects in a more explicit way, and further analyse which specific aspects of the country context are important in understanding these FDI inflows in Table 5, we introduce country level explanatory variables. As explained in the previous section, these variables include LGDPPC, WGI, BIZDAYS, INFLATION, LABOURPARTICIPATION, LEGALRIGHTS, TAXRATE, KAOPEN, and OPENK. We first introduce the macroeconomic variables in estimations (12) and (15).

In the estimations that include country variables, we first note that the coefficients on the firm level variables remain more or less the same as in previous estimations. Among the macro level variables, the GDP per capita of the host country (LGDPPC) has a negative and strongly significant impact. GDP per capita reflects the overall development of a country; we find that FDI is attracted to countries with a lower level of development as it might imply higher economic profitability. This is in line with our finding that lack of proper infrastructural facilities of transportation and electricity lead to higher FDI ownership. This is perhaps substituting for trade. LABOURPARTICIPATION is significant at a 5\% level and has the expected sign. TAXRATE has a positive but a very small coefficient. It does not have the expected sign across the estimations and is not stable across all specifications. INFLATION has a negative impact, suggesting that macroeconomic stability discourages FDI. This variable is significant across all the specifications as well. Both these variables are significant at the 5\% level. In (11) and (14) we exclude LGDPPC and include the institutional variables. WGI is negative and significant at the $5 \%$ level, implying that low institutional

\footnotetext{
${ }^{10}$ We show the results for the estimations with INFRA 1 and INFRA 2; the results are similar for estimations with PHYSICAL 1 and PHYSICAL 2 and FINANCIAL as well and hence have not been included here.

${ }^{11}$ The general rule of thumb says that a VIF $>10$ is harmful.
} 
quality at the country level is detrimental to FDI flows as we had expected. This is interesting since the institutional variables at the firm level were never significant. LEGAL RIGHTS and BIZDAYS are also negative but insignificant. When we include both LGDPPC and the institutional variables, (as in estimations 14 and 17) we find that WGI loses significant. This is expected since LGDPPC and WGI are correlated ${ }^{12}$. Further the interaction terms of the size of the firm and WGI shows that while large firms are not affected by the country's institutional set up, it is the medium sized firms that are impacted negatively as compared to small firms. This could be because larger firms can "grease" their way through and small firms aim to establish themselves in foreign countries for much smaller profit margins. It is the medium sized firms that do not profit from paying their way through, and yet cannot discount possible institutional hurdles that might arise after entry. OPENK is positive and significant at a 5\% level implying that the more trade openness a country has, the greater the FDI, implying vertical FDI. However, the coefficients are rather small in this case.

Looking at the inter class correlations, we find that the values of $\rho$ in estimations (10) and (15) drop down to 0.22 to around $0.15-0.16$ when we include country level determinants. This means that although the country characteristics that were introduced through the new variables are significant, there is still a sizable country variation that is unobserved. Comparing to $\rho=0.124$ of estimation (1), we also note that the firm-level variables that introduced captured a larger part of firm-variation than the country-level variables did for country variation. While the country level variables don't exhaustively explain the country variance, LGDPPC and LABOURPARTICIPATION are the strongest results. We find that the LR tests are significant.

Table 5: Estimations of firm and country level variables without INS and SKILL

\begin{tabular}{|c|c|c|c|c|c|c|}
\hline & (12) & (13) & (14) & (15) & (16) & (17) \\
\hline VARIABLES & FDI & FDI & FDI & FDI & FDI & FDI \\
\hline \multirow[t]{2}{*}{ LNAGE } & $-0.25 * * *$ & $-0.25 * * *$ & $-0.25 * * *$ & $-0.25 * * *$ & $-0.25 * * *$ & $-0.25 * * *$ \\
\hline & $(0.022)$ & $(0.022)$ & $(0.022)$ & $(0.022)$ & $(0.022)$ & $(0.022)$ \\
\hline \multirow[t]{2}{*}{ MEDIUM } & $0.89 * * *$ & $0.88 * * *$ & $0.89 * * *$ & $0.89 * * *$ & $0.89 * * *$ & $0.89 * * *$ \\
\hline & $(0.042)$ & $(0.042)$ & $(0.042)$ & $(0.042)$ & $(0.042)$ & $(0.042)$ \\
\hline \multirow[t]{2}{*}{ LARGE } & $2.026 * * *$ & $2.018 * * *$ & $2.024 * * *$ & $2.025 * * *$ & $2.017 * * *$ & $2.023 * * *$ \\
\hline & $(0.046)$ & $(0.046)$ & $(0.046)$ & $(0.046)$ & $(0.046)$ & $(0.046)$ \\
\hline \multirow[t]{2}{*}{ AGLOM } & $0.024 * * *$ & $0.025 * * *$ & $0.025^{* * *}$ & $0.024 * * *$ & $0.025 * * *$ & $0.025 * * *$ \\
\hline & $(0.001)$ & $(0.001)$ & $(0.001)$ & $(0.001)$ & $(0.001)$ & $(0.001)$ \\
\hline \multirow[t]{2}{*}{ INFRA 1} & $-0.43 * * *$ & $-0.41 * * *$ & $-0.43 * * *$ & & & \\
\hline & $(0.049)$ & $(0.05)$ & $(0.05)$ & & & \\
\hline \multirow[t]{2}{*}{ INFRA 2} & $0.37 * * *$ & $0.36^{* * *}$ & $0.37 * * *$ & & & \\
\hline & $(0.045)$ & $(0.045)$ & $(0.045)$ & & & \\
\hline \multirow[t]{2}{*}{ PHYSICAL 1} & & & & $-0.52 * * *$ & $-0.5 * * *$ & $-0.52 * * *$ \\
\hline & & & & $(0.048)$ & $(0.048)$ & $(0.049)$ \\
\hline \multirow[t]{2}{*}{ PHYSICAL 2} & & & & $0.16^{* * *}$ & $0.16^{* * *}$ & $0.16^{* * *}$ \\
\hline & & & & $(0.055)$ & $(0.055)$ & $(0.055)$ \\
\hline \multirow[t]{2}{*}{ FINANCIAL } & & & & $-0.24 * * *$ & $-0.24 * * *$ & $-0.24 * * *$ \\
\hline & & & & $(0.05)$ & $(0.05)$ & $(0.05)$ \\
\hline \multirow[t]{2}{*}{ LGDPPC } & $-0.24 * * *$ & & $-0.25 * * *$ & $-0.22 * * *$ & & $-0.24 * * *$ \\
\hline & $(0.065)$ & & $(0.078)$ & $(0.065)$ & & $(0.077)$ \\
\hline \multirow[t]{2}{*}{ WGI } & & $-0.07 *$ & 0.008 & & -0.062 & 0.013 \\
\hline & & $(0.041)$ & $(0.047)$ & & $(0.04)$ & $(0.046)$ \\
\hline \multirow[t]{2}{*}{ WGI*MEDIUM } & $-0.06 * * *$ & $-0.06 * * *$ & $-0.06 * * *$ & $-0.06^{* * *}$ & $-0.06 * * *$ & $-0.06 * * *$ \\
\hline & $(0.018)$ & $(0.018)$ & $(0.018)$ & $(0.018)$ & $(0.018)$ & $(0.018)$ \\
\hline \multirow[t]{2}{*}{ WGI*LARGE } & -0.025 & -0.025 & -0.025 & -0.026 & -0.026 & -0.026 \\
\hline & $(0.019)$ & $(0.019)$ & $(0.019)$ & $(0.019)$ & $(0.019)$ & $(0.019)$ \\
\hline
\end{tabular}

\footnotetext{
${ }^{12}$ The correlation between WGI and LGDPPC is nearly 0.68 .
} 


\begin{tabular}{|c|c|c|c|c|c|c|}
\hline & (12) & (13) & (14) & (15) & (16) & (17) \\
\hline VARIABLES & FDI & FDI & FDI & FDI & FDI & FDI \\
\hline \multirow[t]{2}{*}{ BIZDAYS } & & -0.001 & -0.001 & & -0.001 & -0.001 \\
\hline & & $(0.001)$ & $(0.001)$ & & $(0.001)$ & $(0.001)$ \\
\hline \multirow[t]{2}{*}{ INFLATION } & $-0.017 * *$ & $-0.017^{* *}$ & $-0.017^{* *}$ & $-0.016^{* *}$ & $-0.016^{* *}$ & $-0.017 * *$ \\
\hline & $(0.007)$ & $(0.007)$ & $(0.007)$ & $(0.007)$ & $(0.007)$ & $(0.007)$ \\
\hline \multirow[t]{2}{*}{ LABOUR PARTICIPATION } & $0.022 * * *$ & $0.028 * * *$ & $0.02 * *$ & $0.023 * * *$ & $0.028 * * *$ & $0.021 * *$ \\
\hline & $(0.008)$ & $(0.008)$ & $(0.008)$ & $(0.008)$ & $(0.008)$ & $(0.008)$ \\
\hline \multirow[t]{2}{*}{ LEGALRIGHTS } & & -0.029 & -0.03 & & -0.03 & -0.032 \\
\hline & & $(0.029)$ & $(0.028)$ & & $(0.029)$ & $(0.028)$ \\
\hline \multirow[t]{2}{*}{ TAX RATE } & $0.003^{*}$ & $0.003 *$ & 0.002 & $0.003 *$ & $0.003 *$ & 0.0024 \\
\hline & $(0.001)$ & $(0.001)$ & $(0.001)$ & $(0.001)$ & $(0.001)$ & $(0.001)$ \\
\hline \multirow[t]{2}{*}{ KAOPEN } & -0.054 & -0.045 & -0.058 & -0.058 & -0.051 & -0.064 \\
\hline & $(0.048)$ & $(0.05)$ & $(0.049)$ & $(0.048)$ & $(0.05)$ & $(0.049)$ \\
\hline \multirow[t]{2}{*}{ OPENK } & $0.005^{* *}$ & $0.004 * *$ & $0.005^{* *}$ & $0.005^{* *}$ & $0.004^{* *}$ & $0.005 * *$ \\
\hline & $(0.002)$ & $(0.002)$ & $(0.002)$ & $(0.002)$ & $(0.002)$ & $(0.002)$ \\
\hline \multirow[t]{2}{*}{ Constant } & $-2.49 * * *$ & $-4.51 * * *$ & $-2.08^{* *}$ & $-2.25 * *$ & $-4.11 * * *$ & $-1.79 *$ \\
\hline & $(0.883)$ & $(0.660)$ & $(1.002)$ & $(0.884)$ & $(0.662)$ & (1.004) \\
\hline$\rho$ & 0.15 & 0.16 & 0.15 & 0.15 & 0.15 & 0.15 \\
\hline LR Chi2 & 1318.53 & 1318.00 & 1306.16 & 1332.83 & 1331.82 & 1320.51 \\
\hline LR df(1) & $* * *$ & $* * *$ & $* * *$ & $* * *$ & $* * *$ & $* * *$ \\
\hline \# of firms & 43,403 & 43,403 & 43,403 & 43,403 & 43,403 & 43,403 \\
\hline$\#$ of countries & 103 & 103 & 103 & 103 & 103 & 103 \\
\hline
\end{tabular}

Standard errors in parentheses

$* * * \mathrm{p}<0.01, * * \mathrm{p}<0.05, * \mathrm{p}<0.1$

All estimations include Sector dummies.

In Table 6 we include INS and SKILL at the firm level along with the country level variables. Like in the case of estimations (6) to (9) we find that institutional obstacles at the firm level have no significant impact on FDI decisions. On the other hand, SKILL is highly significant and negative. The remaining firm level variables do not change much from the previous estimations. We reiterate that firms entering developing country markets are attracted by profits but are dissuaded if they do not have the required skill in production of goods. Firms may enter developing country markets which have the required skill and also have relatively cheap labour as compared to their country of origin, which can be seen from the significant LABOUR PARITICIPATION variable at the country level.

For the remaining country level variables, the results are very similar to those discussed in Table 4 above. For these estimations, the inter class correlations are $0.14-0.15$. Hence we again find that the overall development of a country and its macroeconomic situation are more important than the institutional quality at the country level. Recognising that WGI and LGDPPC are correlated, we still find that the LGDPPC has a greater significance than WGI and thus we conclude that LGDPPC has a bigger influence on FDI than WGI. Here again we find that medium sized firms are strongly affected by the country institutional set up as compared to small firms. Large firms on the other hand are not significantly affected ${ }^{13}$.

\footnotetext{
${ }^{13}$ Including WGI as a geographically weighted measure (taking into account spatial influence of neighbouring countries in a country's institutions -as discussed in Chapters $3 \& 4$ ) we find that the results are not influenced in anyway. The reason for this could be that the scaling effect at the country level is lost on firm-level decisions. That is, the influence of the institutional quality of neighbouring countries on a country's own institutions has no bearing a firm's decision to enter a country. Further, the model's parsimony might be lost in including such scaling effects when we attempt to understand firm-level decisions given a country's macroeconomic and institutional structure,
} 
Table 6: Estimations of firm and country level variables with INS and SKILL

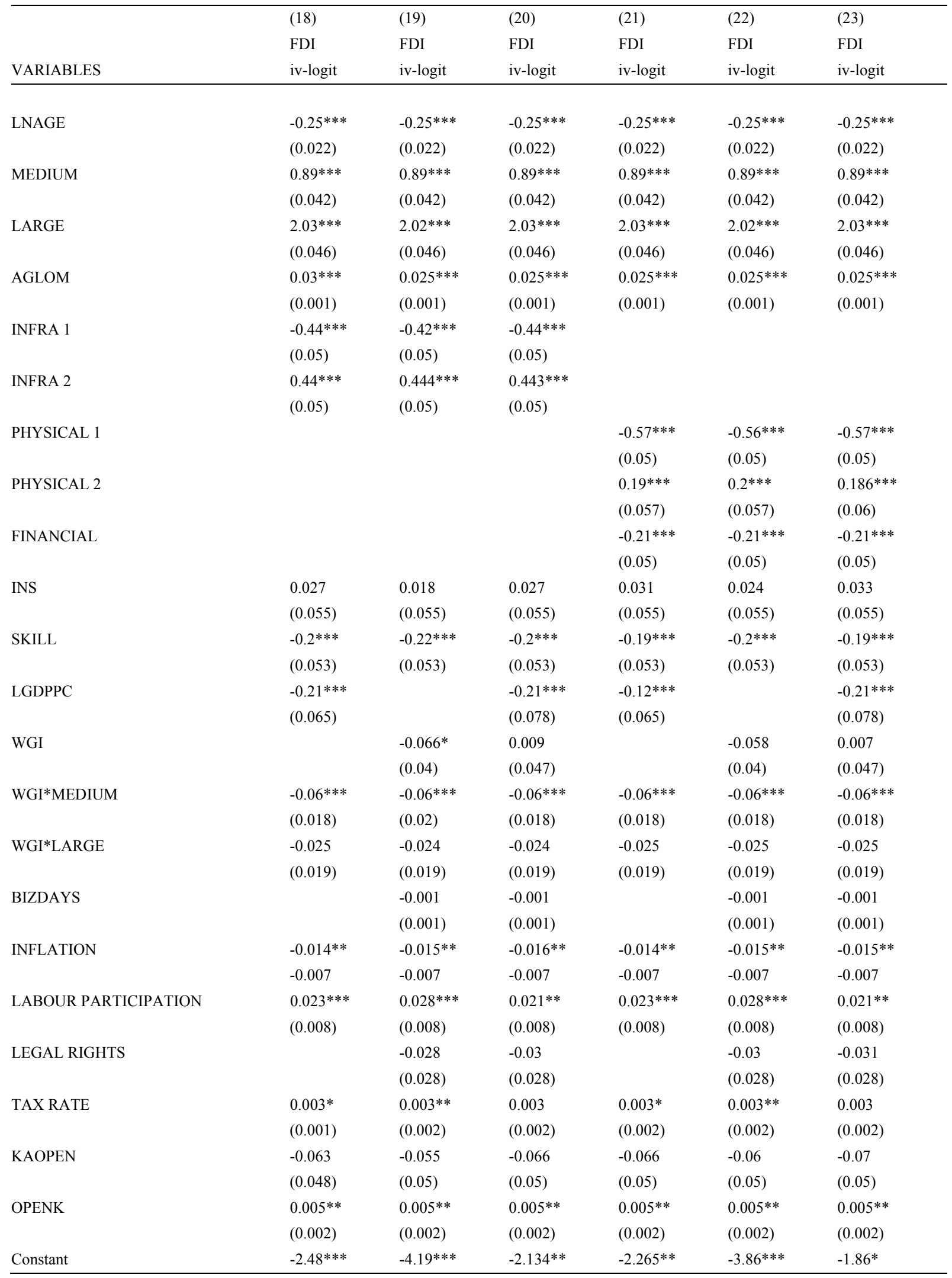




\begin{tabular}{lllllll}
\hline & $(18)$ & $(19)$ & $(20)$ & $(21)$ & $(22)$ & $(23)$ \\
& FDI & FDI & FDI & FDI & FDI & FDI \\
VARIABLES & iv-logit & iv-logit & iv-logit & iv-logit & iv-logit & iv-logit \\
\hline & $(0.88)$ & $(0.65)$ & $(0.99)$ & $(0.88)$ & $(0.66)$ & $(1.00)$ \\
$\rho$ & 0.15 & 0.15 & 0.14 & 0.14 & 0.15 & 0.14 \\
LR Chi2 & 1237.5 & 1222.48 & 1226.21 & 1248.48 & 1234.81 & 1237.56 \\
LR df(1) & $* * *$ & $* * *$ & $* * *$ & $* * *$ & $* * *$ & $* * *$ \\
\# of firms & 43,403 & 43,403 & 43,403 & 43,403 & 43,403 & 43,403 \\
\# of countries & 103 & 103 & 103 & 103 & 103 & 103 \\
\hline
\end{tabular}

Standard errors in parentheses

$* * * \mathrm{p}<0.01, * * \mathrm{p}<0.05, * \mathrm{p}<0.1$

All estimations include Sector dummies.

\section{Conclusions}

Attracting FDI inflows has been argued to help developing countries induce economic growth. While many policies are made by these countries to attract MNE's to invest in their markets, firm decisions on entering new markets are based both on their own idiosyncratic characteristics as well as host country characteristics. Using firm and country data in a multilevel framework, we analyse how obstacles faced by firms both at the operational level and the macroeconomic and institutional situation in a country affect FDI inflows into developing countries. We find from our analysis that a firm's age and size are strongly statistically significant in all the regressions. We consider constraints that are divided into physical infrastructure and financial access constraints, skill and institutional constraints. When considering a micro level analysis we find that internet availability problems are detrimental to FDI decisions. The lack of physical infrastructure facilities such as electricity and transportation on the other hand are found to be encouraging inward FDI. Lack of skilled labour is found to be detrimental to FDI while institutional obstacles such as corruption and crime are not seen as an important determinant.

As emphasised by Dunning (2001) and Rugman $(1980,1981)$ we can say that FDI inflows, while largely explained by firm specific idiosyncrasies, do go hand in hand with host country conditions. Host country conduciveness does play a small but significant role in explaining the attractiveness of FDI inflows. We find that the macroeconomic variables such as LGDPPC, LABOUR PARTICIPATION, and to a smaller extent INFLATION, OPENK and TAXRATES affect FDI decisions on FDI inflows. Institutions measured as WGI at the country level are never significant except when considered without accounting for overall development. Since the overall development of a country has a bearing on the institutional quality of the country this is expected. This is consistent across all specifications.

While many macro studies such as Al-Sadig (2009), Seyoum (2009) and Anghel (2005) among others have found institutions to be an important element in attracting FDI, we find that this is not the case here, when we take both firm level and country level variables into account in a multilevel regression. One reason being that overall development of a country already captures the country institutional set up. Further, country level perceptions measures of institutions are often biased by the macroeconomic situation of the country. At the firm level however, firms might not be as biased towards their perceptions of crime. Their perception on crime and corruption are based on based on day to day activities of businesses. This creates a disparity between the levels of importance given to institutions at both levels. Secondly, profitability of MNE's is dependent on how they can overcome these problems at the least possible cost in the host country. It is likely that certain business costs, even if large, are worth incurring, if long term profits are anticipated. This is further confirmed by the fact that while foreign firms are more likely to be larger firms, these costs do not deter them from entering a country with a bad institutional set up, if the profitability is high.

We could conclude from this that FDI inflows into a country are largely influenced by firm idiosyncratic factors and partially on the general macroeconomic conditions and hardly so on the institutional environment of host countries. As economic fundamentals tend to increase returns to investment, a certain level of uncertainty of crime, corruption and expropriation of wealth seem to be unimportant. FDI decisions are thus neither made solely based on firm characteristics, nor are they based entirely on host country conduciveness for business. We find that the constraints 
reported by firms do reflect country characteristics and their levels of income and overall development, which are small yet significant. Hence we conclude that it is necessary to look at firm level activities such as FDI in a multilevel manner rather than at single levels. 


\section{Appendix}

Table (A): Variable descriptions

\begin{tabular}{|c|c|c|}
\hline Spatial Level/ Scale & Variable & Variable description \\
\hline $\begin{array}{l}\text { Firm-level dependent } \\
\text { variable }\end{array}$ & FDI & $\begin{array}{l}\text { Dummy variable: } \\
0=\text { domestic firms } \\
1=\text { at least } 10 \% \text { of their capital owned by foreign persons or } \\
\text { organisations }\end{array}$ \\
\hline \multirow{8}{*}{$\begin{array}{l}\text { Firm-level independent } \\
\text { variables }\end{array}$} & Lnage & Age of the firm \\
\hline & Size & $\begin{array}{l}1=<20 \text { employees }(\text { base }) \\
2=\text { medium }(20-99) \\
3=\operatorname{large}(>100)\end{array}$ \\
\hline & Infra & $\begin{array}{l}\text { Overall infrastructural obstacles firms face } \\
\text { Obtained from the scores of Component } 1 \text { of PCA (electricity, } \\
\text { transportation, email, web, financial) }\end{array}$ \\
\hline & Physical & $\begin{array}{l}\text { Physical infrastructure obstacles firms face } \\
\text { Obtained from the scores of Component } 1 \text { of PCA (electricity, } \\
\text { transportation, email, web) }\end{array}$ \\
\hline & Financial & Obstacles to financial access \\
\hline & Ins & $\begin{array}{l}\text { Institutional quality. Obtained from the scores of Component } 1 \\
\text { of PCA (corruption, crime and proprights) }\end{array}$ \\
\hline & Skill & Obstacle due to lack of skilled labour. \\
\hline & Aglom & number of foreign firms present in a sector-region \\
\hline \multirow{9}{*}{$\begin{array}{l}\text { Country-level } \\
\text { independent variables }\end{array}$} & Lgdppc & GDP per capita (log of current USD prices) \\
\hline & WGI & $\begin{array}{l}\text { Measure of Governance Obtained from the scores of } \\
\text { Component } 1 \text { of PCA of the } 6 \text { World Governance Indicators }\end{array}$ \\
\hline & Bizdays & number of calendar days required to start a business \\
\hline & Legal rights & $\begin{array}{l}\text { degree of protection given to lenders and borrowers, given the } \\
\text { country's bankruptcy laws }\end{array}$ \\
\hline & Tax rates & tax rate ( $\%$ commercial profits) \\
\hline & Kaopen & $\begin{array}{l}\text { Financial openness measured by "extent and intensity" of } \\
\text { capital controls of countries }\end{array}$ \\
\hline & Openk & $\begin{array}{l}\text { openness to trade measured by net exports as a percentage of } \\
\text { GDP }\end{array}$ \\
\hline & labourparticipation & $\begin{array}{l}\text { proportion of working age population which is economically } \\
\text { active }\end{array}$ \\
\hline & inflation & growth rate of the GDP deflator \\
\hline
\end{tabular}




\section{Table (B): World Governance Indicators}

$\begin{array}{ll}\text { Voice and accountability } & \begin{array}{l}\text { Perceptions of freedom of citizen's in choosing their government } \\ \text { as well as freedom of press }\end{array} \\ \text { Political Stability and Absence of Violence } & \begin{array}{l}\text { Perceptions on the stability of government and on the presence } \\ \text { of political violence and terrorism }\end{array} \\ \text { Government Effectiveness } & \begin{array}{l}\text { Perceptions on the quality of public and civil services as well we } \\ \text { effective government policies and their credibility }\end{array} \\ \text { Regulatory Quality } & \begin{array}{l}\text { Perceptions on government regulation, and its ability to foster } \\ \text { private sector development }\end{array} \\ \text { Rule of Law } & \begin{array}{l}\text { Perceptions on the quality of contract enforcement, property } \\ \text { rights, the police, and the courts, as well as the likelihood of } \\ \text { crime and violence }\end{array} \\ \text { Control of Corruption } & \begin{array}{l}\text { Perceptions on corruption and the power elites and private } \\ \text { interests. }\end{array}\end{array}$

Source: www.govindicators.org

Table (C): List of countries in the larger sample:

\begin{tabular}{|c|c|c|c|}
\hline Afghanistan & Costa Rica & Latvia & Rwanda \\
\hline Albania & Cote d'Ivoire & Lesotho & Samoa \\
\hline Angola & Croatia & Liberia & Senegal \\
\hline Argentina & Czech Republic & Lithuania & Sierra Leone \\
\hline Armenia & Dominican Republic & Macedonia, FYR & Slovak Republic \\
\hline Azerbaijan & Ecuador & Madagascar & Slovenia \\
\hline Bahamas, The & El Salvador & Malawi & South Africa \\
\hline Bangladesh & Eritrea & Mali & St. Lucia \\
\hline Belarus & Estonia & Mauritania & St. Vincent \& the Grenadines \\
\hline Belize & Fiji & Mauritius & Suriname \\
\hline Benin & Gabon & Mexico & Swaziland \\
\hline Bhutan & Gambia, The & Moldova & Tajikistan \\
\hline Bolivia & Georgia & Mongolia & Tanzania \\
\hline Bosnia and Herzegovina & Ghana & Mozambique & Togo \\
\hline Botswana & Guatemala & Namibia & Tonga \\
\hline Brazil & Guinea & Nepal & Trinidad and Tobago \\
\hline Bulgaria & Guinea-Bissau & Nicaragua & Turkey \\
\hline Burkina Faso & Guyana,Co-op Republic of & Niger & Uganda \\
\hline Burundi & Honduras & Pakistan & Ukraine \\
\hline Cameroon & Hungary & Panama & Uruguay \\
\hline Cape Verde & Indonesia & Paraguay & Uzbekistan \\
\hline Chad & Jamaica & Peru & Venezuela, RB \\
\hline Chile & Kazakhstan & Philippines & Vietnam \\
\hline Colombia & Kenya & Poland & Yemen, Rep. \\
\hline Congo, Dem. Rep. & Kyrgyz Republic & Romania & Zambia \\
\hline Congo, Rep. & Lao PDR & Russian Federation & \\
\hline
\end{tabular}




\section{Bibliography}

Adams, S. (2009). "Foreign Direct investment, domestic investment, and economic growth in Sub-Saharan Africa". Journal of Policy Modeling, 31(6), 939-949.

Alfaro, L., Chanda, A., Kalemli-Ozcan, S., \& Sayek, S. (2010). "Does foreign direct investment promote growth? Exploring the role of financial markets on linkages". Journal of Development Economics, 91(2), 242-256.

Alguacil, M., Cuadros, A., \& Orts, V. (2011). "Inward FDI and growth: The role of macroeconomic and institutional environment". Journal of Policy Modeling, 33(3), 481-496.

Al-Sadig, A. (2009). "Effects of Corruption on FDI Inflows", The Cato J., 29, 267.

Anghel, B. (2005). "Do institutions affect foreign direct investment?" International Doctorate in Economic Analysis, 2-40.

Aristotelous, K., \& Fountas, S. (1996). "An Empirical Analysis of Inward Foreign Direct Investment Flows in the EU with Emphasis on the Market Enlargement Hypothesis". JCMS: Journal of Common Market Studies, 34(4), 571-583.

Aseidu, E., (2002), "On the Determinants of Foreign Direct Investment to Developing Countries: Is Africa Different?", World Development, Vol 30, No. 1, pp 107-119.

Aterido, R., Hallward-Driemeier, M., \& Pages, C. (2007). "Investment climate and employment growth: The impact of access to finance, corruption and regulations across firms". Inter-American Development Bank Working Paper No. 626.

Baer, W., \& Sirohi, R. A. (2013). "The Role of Foreign Direct Investments in the Development of Brazil and India: A Comparative Analysis". Kyklos, 66(1), 46-62.

Bénassy-Quéré, A., Coupet, M., \& Mayer, T. (2007). "Institutional determinants of foreign direct investment". The World Economy, 30(5), 764782 .

Blonigen, B. (2005). "A Review of the Empirical Literature on FDI Determinants," Atlantic Economic Journal, International Atlantic Economic Society, vol. 33(4), pages 383-403, December.

Buckley, P. J., Devinney, T. M., \& Louviere, J. J. (2007d). "Do managers behave the way theory suggests? A choice theoretic examination of foreign direct investment location decision making". Journal of International Business Studies, 38 (7), 1069-1094.

Busse, M., \& Hefeker, C. (2007). "Political risk, institutions and foreign direct investment". European Journal of Political Economy, 23(2), 397415.

Chinn, M. D., \& Ito, H. (2008). "A new measure of financial openness. Journal of Comparative Policy Analysis", 10(3), $309-322$.

Daude, C., \& Stein, E. (2007). "The quality of institutions and foreign direct investment". Economics \& Politics, 19(3), $317-344$.

Delbecque, V., Méjean, I., \& Patureau, L. (2008). "Social competition and firms' location choices". Centre D'études Prospectives Et d'informations Internationales (CEPII) Working Paper, 12.

Devereux, M., \& Freeman, H., (1995). "The impact of tax on foreign direct investment: Empirical evidence and the implications for tax integration schemes," International Tax and Public Finance, Springer, vol. 2(1), pp 85-106, February.

Dollar, D., Hallward-Driemeier, M., \& Mengistae, T. (2005). "Investment Climate and Firm Performance in Developing Economies". Economic Development and Cultural Change, 54(1), 1-31

Dollar, D., Hallward-Driemeier, M., \& Mengistae, T. (2006). "Investment climate and international integration". World Development, 34 (9), $1498-1516$.

Dunning, J. H., (1988), “Trade, Location and Economic Activity anf the Multinational enterprise: A Search for an Eclectic Approach”, Ch. 1, Pg 13-40, in Dunning, John H., "Explaining International Production", Unwin Hyman, London, ISBN- 0-04-44517-9.

Dunning, J. H., (2001). "The eclectic (OLI) paradigm of international production: past, present and future". International journal of the economics of business, 8(2), 173-190.

Gelb, A., Ramachandran, V., Shah, M. K., \& Turner, G. (2007). What matters to African firms. The relevance of perceptions data, World Bank Policy Research Working Paper, (4446).

Goedhuys, M. \& Srholec, M., 2010. "Understanding multilevel interactions in economic development," MERIT Working Papers 003, United Nations University - Maastricht Economic and Social Research Institute on Innovation and Technology (MERIT).

Goldstein, H. (2003). Multilevel statistical models . London: Edward Arnold.

Hartman, D. G. (1984). "Tax policy and foreign direct investment in the United States". National Tax Journal, 475-487.

Hartman, D. G. (1985). "Tax policy and foreign direct investment". Journal of Public economics, 26(1), 107-121.

Heston, A., \& Summers, R., and Aten, B. (2012): Penn World Table Version 7.1. Center for International Comparisons of Production, Income and Prices at the University of Pennsylvania.

Kaufmann, D., \& Wei, S. J. (1999). "Does" grease money" speed up the wheels of commerce?" (No. w7093). National bureau of economic research.

Kinda, T. (2010). "Investment climate and FDI in developing countries: firm-level evidence". World Development, 38(4), 498-513.

Lee, I. H. and Rugman, A. M. (2012). "Firm-specific advantages, inward FDI origins, and performance of multinational enterprises", Journal of International Management, 18, issue 2, p. 132-146

Meentemeyer, V. (1989). "Geographical perspectives of space, time, and scale". Landscape ecology, 3(3-4), 163-173.

Naude, W. A. \& Krugell, W. F. 2007. "Investigating geography and institutions as determinants of foreign direct investment in Africa using panel data," Applied Economics, Taylor \& Francis Journals, vol. 39(10), pages 1223-1233.

Pajunen, K. (2008). "Institutions and inflows of foreign direct investment: A fuzzy-set analysis". Journal of International Business Studies, 39(4), 652-669.

Rabe-Hesketh, S., \& Skrondal, A. (2008). Multilevel and longitudinal modelling using Stata. STATA press.

Rugman, A. M. (1980). "Internalization as a general theory of foreign direct investment: A re-appraisal of the literature". Review of World Economics, 116(2), 365-379.

Rugman, A.M. 1981. Inside the multinationals. London: Croom Helm. 
Sato, T. (2012). "Empirical Analysis of Corporate Tax and Foreign Direct Investment". Public Policy Review, 8(1), 1-20.

Seyoum, B. (2009). "Formal institutions and foreign direct investment". Thunderbird International Business Review, 51(2), 165-181.

Seyoum, B. (2011). Informal institutions and foreign direct investment. Journal of Economic Issues, 45(4), 917-940.

Sharma, K. \& Bandara, Y. (2010). Trends, patterns and determinants of Australian foreign direct investment. Journal of Economic Issues, 64 (3), 661-676.

Singh, H., \& Jun, K. (1995). "Some new evidence on determinants of foreign direct investment in developing countries". World Bank Policy Research Working Paper, (1531).

Smarzynska, B. K., \& Wei, S. J. (2000). "Corruption and composition of foreign direct investment: Firm-level evidence". (No. w7969). National Bureau of Economic Research.

Srholec, M. (2010). "A multilevel approach to geography of innovation". Regional Studies, 44(9), 1207-1220.

Stein, E., \& Daude, C. (2002). "Institutions, Integration and the Location of Foreign Direct Investment. New Horizons for Foreign Direct Investment", (548), 101.

Walsh, J. P., \& Yu, J. (2010). "Determinants of foreign direct investment: A sectoral and institutional approach". (Vol. 10). International Monetary Fund.

Wei, S. J. (2000). "How taxing is corruption on international investors?". Review of economics and statistics, 82(1), 1-11.

Wernick, D. A., Haar, J., \& Singh, S. (2009). "Do governing institutions affect foreign direct investment inflows? New evidence from emerging economies". International Journal of Economics and Business Research, 1(3), 317-332.

Wheeler, D., \& Mody, A. (1992). "International investment location decisions: The case of US firms". Journal of International Economics, 33(12), 57-76. 


\section{The UNU-MERIT WORKING Paper Series}

2014-01 The medium-term effect of R\&D on firm growth by Marco Capasso, Tania Treibich and Bart Verspagen

2014-02 Diverse and uneven pathways towards transition to low carbon development: The case of diffusion of solar PV technology in ChinaMichiko lizuka

2014-03 User innovators and their influence on innovation activities of firms in Finland by JariKuusisto, MerviNiemi and Fred Gault

2014-04 Migration, remittances and household welfare in Ethiopia by Lisa Andersson

2014-05 Path-breaking directions of nanotechnology-based chemotherapy and molecular cancer therapy by Mario Coccia and Lili Wang

2014-06 Poor trends - The pace of poverty reduction after the Millennium Development AgendaRichard Bluhm, Denis de Crombrugghe, Adam Szirmai

2014-07 Firms' adoption of international standards: Evidence from the Ethiopian floriculture sector by MuluGebreeyesu

2014-08School choice, segregation, and forced school closureby Cheng Boon Ong andKristof De Witte

2014-09Gender difference in support for democracy in Sub-Saharan Africa: Do social institutions matter?by MatyKonte

2014-10 Why are women less democratic than men? Evidence from Sub-Saharan African countries by Cecilia García-Peñalosa and MatyKonte

2014-11 Tipping points? Ethnic composition change in Dutch big city neighbourhoods by Cheng Boon Ong

2014-12 Technology life cycle and specialization patterns of latecomer countries. The case of the semiconductor industry by Giorgio Triulzi

2014-13 Patents as quality signals? The implications for financing constraints on $R \& D$ by Dirk Czarnitzki, Bronwyn H. Hall and Hanna Hottenrott

2014-14 Assessment of effectiveness of Chinese aid in competence building and financing development in Sudan by SamiaSatti Osman Mohamed Nour

2014-15Education, training and skill development policies in Arab Gulf countries: Macromicro overview by SamiaSatti Osman Mohamed Nour

2014-16 Structure of labour market and unemployment in Sudan by SamiaSatti Osman Mohamed Nour

2014-17 Overview of knowledge transfer in MENA countries - The case of Egypt by SamiaSatti Osman Mohamed Nour

2014-18 The impact of ICT in public and private universities in Sudanby SamiaSatti Osman Mohamed Nour

2014-19End-user collaboration for process innovation in services: The role of internal resources by Mona Ashok, Rajneesh Narula and Andrea Martinez-Noya

2014-20 Public investment and regional politics: The case of Turkey by Mehmet Guney Celbis, Denis de Crombrugghe and Joan Muysken

2014-21 Infrastructure and the international export performance of Turkish regions by Mehmet Guney Celbis, Peter Nijkamp and Jacques Poot

2014-22 Discovering and explaining work-family strategies of parents in Luxembourg by Nevena Zhelyazkova

2014-23Parental leave take up and return to work of mothers in Luxembourg: An application of the model of nested dichotomies by Nevena Zhelyazkova 
2014-24 Millennium Development Goals: Tool or token of global social governance? by Mueid Al Raee, Elvis Amoateng, Elvis Korku Avenyo, Youssef Beshay, Mira Bierbaum, Charlotte Keijser and Rashmi Sinha

2014-25 One Europe or several? Causes and consequences of the European stagnation by Jan Fagerberg and Bart Verspagen

2014-26 The harmony of programs package: Quasi-experimental evidence on deworming and canteen interventions in rural Senegal by Théophile Azomahou, Fatoumata Diallo and Wladimir Raymond

2014-27 Country Terms of Trade 1960-2012: Trends, unit roots, over-differencing, endogeneity, time dummies, and heterogeneity by Thomas Ziesemer

2014-28 The structure and comparative advantages of China's scientific research Quantitative and qualitative perspectives by Lili Wang

2014-29 Transition to knowledge-based economy in Saudi Arabia by Samia Satti Osman Mohamed Nour

2014-30 Challenges and opportunities for transition to knowledge-based economy in Arab Gulf countries by Samia Satti Osman Mohamed Nour

2014-31 Migration of international students and mobilizing skills in the MENA Region by Samia Satti Osman Mohamed Nour

2014-32 Beyond product innovation; improving innovation policy support for SMEs in traditional industries by René Wintjes, David Douglas, Jon Fairburn, Hugo Hollanders and Geoffrey Pugh

2014-33 The impact of innovation support programmes on SME innovation in traditional manufacturing industries: an evaluation for seven EU regions by Dragana Radicic, Geoffrey Pugh, Hugo Hollanders and René Wintjes

2014-34 Beliefs dynamics in communication networks by Théophile T. Azomahou and Daniel C. Opolot

2014-35 Stability and strategic diffusion in networks by Théophile T. Azomahou and Daniel C. Opolot

2014-36 Epsilon-stability and the speed of learning in network games by Théophile T. Azomahou and Daniel C. Opolot

2014-37 Afghan unaccompanied minors in the Netherlands: Far away from home and protected? by Carla Buil and Melissa Siegel

2014-38Multinational production and trade in an endogenous growth model with heterogeneous firms by Hibret B. Maemir and Thomas Ziesemer

2014-39 The political economy of research and innovation in organic photovoltaics (OPV) in different world regions by Serdar Türkeli and René Kemp

2014-40 Towards the societal system of innovation: The case of metropolitan areas in Europe by Serdar Türkeli and René Wintjes

2014-41 To return permanently or to return temporarily? Explaining migrants' intentions by Özge Bilgili and Melissa Siegel

2014-42 Catching up and lagging behind in a balance-of-payments-constrained dual economy by Alejandro Lavopa

2014-43 An introduction to the economics of rare earths by Eva Bartekova

2014-44 The unequal effect of India's industrial liberalization on firms' decision to innovate: Do business conditions matter? By Maria Bas and Caroline Paunov

2014-45 Insurgents in motion: Counterinsurgency and insurgency relocation in Iraq by Puihang Wong 
2014-46 Successive leadership changes in the regional jet industry by Daniel Vertesy

2014-47 Demand, credit and macroeconomic dynamics: A microsimulation model by Huub Meijers, Önder Nomaler and Bart Verspagen

2014-48Accessibility analysis as an urban planning tool: Gas station location by D.A. Escobar , C. Cadena-Gaitán, F.J. Garcia

2014-49 China's economic embrace of Africa - An international comparative perspective by Tobias Broich and Adam Szirmai

2014-50 Mapping regional social enterprise ecosystems in India: Framework and indicators by Lina Sonne

2014-51Does shelter assistance reduce poverty in Afghanistan? By Craig Loschmann, Christopher R. Parsons and Melissa Siegel

2014-52 How important is innovation? A Bayesian factor-augmented productivity model on panel data by Georges Bresson, Jean-Michel Etienne and Pierre Mohnen

2014-53 Does too much work hamper innovation? Evidence for diminishing returns of work hours for patent grants by Mehmet Güney Celbi, Serdar Türkeli

2014-54 Globalization, the rise of biotechnology and catching up in agricultural innovation: The case of Bt technology in India Michiko lizuka and Ajay Thutupalli

2014-55 Where are innovation indicators, and their applications, going? by Fred Gault

2014-56 Productivity in services in Latin America and the Caribbean by Elena Arias-Ortiz, Gustavo Crespi, Alejandro Rasteletti and Fernando Vargas

2014-57 Optimal public investment, growth, and consumption: Fresh evidence from African countries by Augustin Kwasi Fosu, Yoseph Yilma Getachew and Thomas H.W. Ziesemer

2014-58 International R\&D alliances by firms: Origins and development by Rajneesh Narula and Andrea Martínez-Noya

2014-59 Appropriability mechanisms, innovation and productivity: Evidence from the UK by Bronwyn H. Hall and Vania Sena

2014-60 The size of patent categories: USPTO 1976-2006 by François Lafond

2014-61Asset recombination in international partnerships as a source of improved innovation capabilities in China by Simon C. Collinson and Rajneesh Narula

2014-62 The viability of sustained growth by India's MNEs: India's dual economy and constraints from location assets by Rajneesh Narula

2014-63 The effect of unconditional cash transfers on adult labour supply: A unitary discrete choice model for the case of Ecuador by Andrés Mideros and Cathal O'Donoghue

2014-64 Giving in South Africa: Determining the influence of altruism, inequality aversion and social capital by Nyasha Tirivayi

2014-65 The impact of food transfers for people living with HIV/AIDS: Evidence from Zambia by Nyasha Tirivayi and Wim Groot

2014-66 Size and economies of scale in higher education and the implications for mergers by Nyasha Tirivayi, Henriette Maasen van den Brink and Wim Groot

2014-67 Widowhood and barriers to seeking health care in Uganda by Nyasha Tirivayi

2014-68 An individual-centered approach to multidimensional poverty: The cases of Chile, Colombia, Ecuador and Peru by Andrea Franco Correa

2014-69 Innovation and productivity in services: Empirical evidence from Latin America by Gustavo Crespi, Ezequiel Tacsir and Fernando Vargas

2014-70 Analysing global value chains using input-output economics: Proceed with care by Önder Nomaler and Bart Verspagen 
2014-71 The deposit financing gap: Another Dutch disease by Huub Meijers, Joan Muysken and Olaf Sleijpen

2014-72 Do remittances and social assistance have different impacts on expenditure patterns of recipient households? The Moldovan case by Jennifer Waidler, Jessica Hagen-Zanker, Franziska Gassmann and Melissa Siegel

2014-73 The role of industry and economic context in open innovation: Evidence from Nigeria by Abiodun Egbetokun, Omolayo Oluwatope, David Adeyeye and Maruf Sanni

2014-74 Means to improve access to justice and legally empower victims of domestic violence: An empirical legal study on legislation and legal offices in Buenos Aires, Argentina by Julieta Marotta

2014-75 Do remittances not promote growth? A bias-adjusted three-step mixture-ofregressions by Maty Konte

2014-76Structural modernization and development traps: An empirical approach by Alejandro Lavopa and Adam Szirmai

2014-77Democratizing intellectual property systems: How corruption hinders equal opportunities for firms by Caroline Paunov

2014-78 Can internet infrastructure help reduce regional disparities? Evidence from Turkey by Mehmet Guney Celbis and Denis de Crombrugghe

2014-79 Obesity of women in Jordan - Prevalence and associated factors: Making a case for a comprehensive obesity policy by Sebastian Göllner and Zina Nimeh

2014-80 International R\&D spillovers and business service innovation by Neil FosterMcGregor, Johannes Pöschl and Robert Stehrer

2014-81 Tax incentives and firm size: effects on private R\&D investment in Spain by José M. Labeaga, Ester Martínez-Ros and Pierre Mohnen

2014-82 The Republic of Open Science: The institution's historical origins and prospects for continued vitality by Paul A. David

2014-83 How can political trust be built after civil wars? Lessons from post-conflict Sierra Leone by Pui-Hang Wong

2014-84 Has the internet fostered inclusive innovation in the developing world? by Caroline Paunov and Valentina Rollo

2014-85 Multi-level determinants of inward FDI ownership by Samyukta Bhupatiraju 